\title{
Culturable vibrios biodiversity in the Northern Ionian Sea (Italian coasts)*
}

\author{
ROSA ANNA CAVALLO and LOREDANA STABILI \\ Istituto Ambiente Marino Costiero, Sezione di Taranto, Talassografico “A. Cerruti”, CNR, 74100 Taranto, Italy. \\ E-mail: cavallo@istta.le.cnr.it
}

\begin{abstract}
SUMMARY: Vibrio spp. in the marine environment play an important role in biodegradation, nutrient regeneration and biogeochemical cycling. These microorganisms are normal residents in coastal waters and their numbers depend on environmental parameters. The qualitative and quantitative composition of culturable Vibrio spp. in water samples from the Northern Ionian Sea (Italy) was investigated. The study was carried out from December 1999 to November 2000 in 10 stations along the coast line between Castellaneta Marina and Santa Maria al Bagno. Seasonal distribution of culturable vibrios densities showed the highest values during the summer-autumn period. Furthermore, in all the examined sites vibrio abundance was higher at the stations nearest the shore. During the sampling period 387 Vibrio spp. strains were isolated. Vibrio mediterranei was the predominant species, $V$. nereis and $V$. harveyi also represented two consistent components of the isolated culturable vibrio community. $V$. alginolyticus and $V$. parahaemolyticus showed a mean isolation percentage of about $7 \%$. Recovery of some vibrio species was correlated with temperature. Data provided in this study will improve our understanding of the distribution of Vibrio species in the Northern Ionian Sea.
\end{abstract}

Key words: vibrios biodiversity, Northern Ionian Sea, Vibrio mediterranei, abiotic parameters.

RESUMEN: BIODIVERSIDAD DE VIBRIONES CULTIVABLES EN EL MAR JÓNICO SEPTENTRIONAL (COSTAS ITALIANAS). - Vibrio spp. en el medio marino desempeña un importante papel en la biodegradación, la regeneración de nutrientes y los ciclos biogeoquímicos. Estos organismos son residentes normales en las aguas costeras y su número depende de parámetros ambientales. Se investigó la composición cualitativa y cuantitativa de Vibrio spp. cultivables en muestras de agua del mar Jónico septentrional (Italia). El estudio se llevó a cabo desde diciembre de 1999 a noviembre de 2000 en 10 estaciones a lo largo de la costa entre Castellaneta Marina y Santa Maria al Bagno. La distribución estacional de las densidades de vibriones cultivables presentó los mayores valores durante el período de verano-otoño. Además, en todas las localidades muestreadas la abundancia de vibriones fue mayor en las estaciones más cercanas a la costa. Durante el período de muestreo se aislaron 387 cepas de 387 Vibrio spp. La especie predominante fue Vibrio mediterranei, y V. nereis y V. harveyi fueron asimismo dos componentes constantes de la comunidad de vibriones cultivables aislados. V. alginolyticus y $V$. parahaemolyticus mostraron un porcentaje medio de aislamiento de alrededor del 7\%. La recuperación de algunas especies de Vibrio estuvo correlacionada con la temperatura. Los datos que se proporcionan en este estudio aumentarán nuestro conocimiento de la distribución de las especies de Vibrio en el mar Jónico septentrional.

Palabras clave: biodiversidad de vibriones, mar Jónico septentrional, Vibrio mediterranei, parámetros abióticos.

\section{INTRODUCTION}

Vibrios are short, Gram-negative rods, natural inhabitants of the aquatic environment in both temperate and tropical climates, usually found both free

*Received September 18, 2001. Accepted November 18, 2002. in the water and bound to animate and inanimate surfaces (Huq et al., 1983; Montanari et al., 1999). Several studies on the role of Vibrio spp. in the marine environment have demonstrated the importance in biodegradation, nutrient regeneration and biogeochemical cycling (Ducklow, 1983; Jorgensen, 1983; Colwell, 1994). Most environmental studies 
on Vibrio spp. have focused on their presence in oysters, clams, mussels, seaweeds, and fish, as well as water, sediment and plankton (Macian et al., 2000 a; Montilla et al., 1995). However, the lack of quantitative data in most of these investigations has impeded progress toward determining sources or niches of these vibrios. Vibrios have frequently been isolated in high densities from the intestines of cultured and wild finfish from Japan, Europe and United States (Colwell, 1962; Sera and Ishida, 1972; Gilmour et al., 1976; Yoshimizu et al., 1976; Sakata et al., 1978; Ugajin, 1979; McFarlane et al., 1986) and were found to be the dominant microflora of fish with well developed digestive systems. High nutrient levels in fish intestines in fact may enhance the growth of vibrios. Some species, such as Vibrio vulnificus and $V$. parahaemolyticus, are halophiles which require a saltwater environment for growth. These microorganisms are normal residents in coastal waters and their numbers depend on environmental parameters (Kaspar and Tamplin, 1993; Miles et al., 1997; Motes et al., 1998). Cell numbers typically increase during the summer as water temperatures rises. Vibrio spp. occurrence is also favoured by relative low salinity. Nutrient insufficiency is the most common environmental stress which vibrios routinely encounter in natural ecosystems. Some Vibrio species are pathogenic for fish and shellfish, as well as for humans. The species implicated in human disease include Vibrio cholerae, V. alginolyticus, V. parahaemolyticus, V. vulnificus, $V$. cincinnatiensis, $V$. fluvialis, $V$. furnissii, $V$. hollisae, V. mimicus, V. metschnikovii and Photobacterium damselae. Furthermore, vibriosis is one of the most important bacterial diseases that affect fish in Southern Europe, with Vibrio anguillarum and $V$.

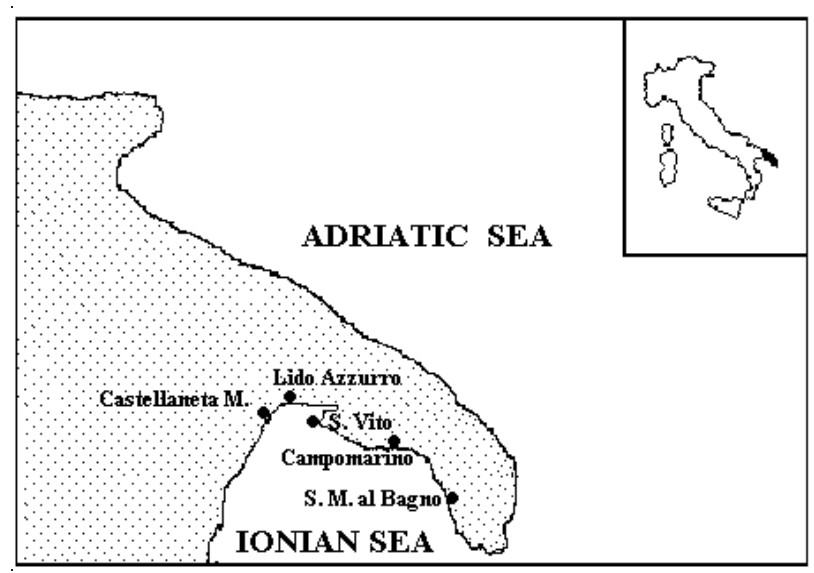

FIG. 1. - Map of the Northern Ionian Sea Italian coast showing the locations of the sampling sites. alginolyticus being two of the species frequently isolated from diseased fish (Bordas et al., 1998). Bacterial adhesion to external surfaces of fish is generally the initial step for colonization. Because of the widespread distribution of vibrios in coastal waters, the monitoring of water for the presence of these microorganisms may provide an early warning for human health and water quality. In this framework, reported here are the results of a study of culturable vibrios in water samples from different coastal sites from the Northern Ionian Sea along Italian Apulian coasts.

\section{MATERIAL AND METHODS}

\section{Sampling methods}

Seawater samples were collected over an annual cycle (from December 1999 to November 2000) in five sites located in the Northern Ionian Sea: Castellaneta Marina, Lido Azzurro, S. Vito, Campomarino and Santa Maria al Bagno. For each site two stations were selected on a transect perpendicular to the shore at 500 and $3000 \mathrm{~m}$ from the coastal line (Fig.1). Water samples were obtained aseptically in presterilized $1000 \mathrm{ml}$ bottles with hermetic stoppers submerged to a depth of $50 \mathrm{~cm}$. The samples were transported on ice and processed for enumeration and isolation of bacteria within $4 \mathrm{~h}$ of sampling.

\section{Abiotic parameters}

Temperature, salinity, and dissolved oxygen were measured in situ using a multiparametric soundingline "Ocean Seaven 401" (Jolzonant, Italy).

\section{Bacteriological methods}

To enumerate the vibrios, 5 and $10 \mathrm{ml}$ of seawater were filtered on $0.22 \mu \mathrm{m}$ pore size filters and the filter disks were aseptically placed onto TCBS agar. After overnight incubation at $20-25$ and $35^{\circ} \mathrm{C}$ the emerging colonies were counted according to the colony-forming units (CFU) method.

In the laboratory, qualitative Vibrio spp. research was carried out by filtering the water samples (500 $\mathrm{ml}$ ) through $0.2 \mu \mathrm{m}$ pore size filters (Millipore). Membranes were incubated in alkaline peptone water (APW) for $24 \mathrm{~h}$ at 35 and $24^{\circ} \mathrm{C}$. The enrichments were then streaked onto thiosulphate-citratebile-salt-agar (TCBS) plus $2 \% \mathrm{NaCl}$ and incubated 
for $24-48 \mathrm{~h}$ at $20-25$ and $35^{\circ} \mathrm{C}$. The incubation temperature of $35^{\circ} \mathrm{C}$ was chosen to give an estimate of vibrios pathogenic to humans. The lower incubation temperature $\left(20-25^{\circ} \mathrm{C}\right)$ was selected since some Vibrio spp., including $V$. anguillarum, do not grow well at $37^{\circ} \mathrm{C}$ (Høi et al., 1998). All the suspected colony types (yellow and green), obtained after the enrichment and from direct plating, were selected, streaked onto TCBS agar plus $2 \% \mathrm{NaCl}$ to obtain pure cultures, screened for cytochrome oxidase, tested for $0 / 129$ sensitivity $(10 \mu \mathrm{g})$, and examined for $\mathrm{NaCl}$ requirement $(0 \%, 6 \%$ and $8 \%)$. Other morphological, biochemical and cultural tests were carried out such as: Gram staining, catalase assay, carbohydrates fermentation on triple sugar iron (TSI) agar plus $2 \% \mathrm{NaCl}$, growth at 4,35 and $40^{\circ} \mathrm{C}$, VogesProskauer assay, citrate assay, indole assay, gelatinase, ONPG hydrolysis, aminoacids decarboxylase reaction (Bergey's Manual of Determinative Bacteriology, 1994; Alsina and Blanch, 1994). After that, a representative sample of isolates $(54 \%)$ was submitted to phenotypic characterization by the mini automated API 20 E identification system ID 32 (Bio Merieux Sa, France) employing 1.7\% sterile saline as inoculum diluent.

\section{Statistical analysis}

The vibrios species densities were log transformed and statistical analysis was performed by using the STATSOFT STATISTICA v. 6.0 (Statsoft 2001) to identify linear regressions and correlation coefficients with temperature.

\section{RESULTS}

The results concerning the abiotic parameters of the investigated area are shown in Table 1 . The temperature mean value was $19.2^{\circ} \mathrm{C}$. The mean oxygen percentage saturation was 112.1 and the mean salinity $38.1 \%$.
Vibrio spp. were enumerated in the surface water samples collected in the Northern Ionian Sea along Italian coasts. The analysis of the annual distribution of culturable vibrios (Figs. 2, 3 and 4) showed that the highest values were usually reached during the summer-autumn period. In all the examined sites vibrio concentrations were higher at the station near the coast than at the one located $3000 \mathrm{~m}$ from the coastal line. Furthermore, vibrio mean densities were higher at the sites nearest to Taranto city. Particularly in Castellaneta Marina (Fig. 2a) the mean value of culturable vibrios was $2.0 \times 10^{1} \mathrm{CFU} \mathrm{ml}^{-1}$ at the station near the coast and $1.2 \times 10^{1} \mathrm{CFU} \mathrm{ml}{ }^{-1}$ $3000 \mathrm{~m}$ from the shore. At $500 \mathrm{~m}$ from the coast the highest value of culturable vibrios was observed in January. At $3000 \mathrm{~m}$ from the coastal line the highest value of culturable vibrios was recorded in August. In Lido Azzurro (Fig. 2b) culturable-vibrio mean density was $1.7 \times 10^{1} \mathrm{CFU} \mathrm{ml}{ }^{-1}$ at the station near the coast and $1.2 \times 10^{1} \mathrm{CFU} \mathrm{ml^{-1 }} 3000 \mathrm{~m}^{-1}$ from the shore and the highest values both at 500 and $3000 \mathrm{~m}$ were monitored in September. In S. Vito (Fig. 2c) the mean value of Vibrio spp. was $2.0 \times 10^{1} \mathrm{CFU} \mathrm{ml}^{-1}$ at the station near the coast and $1.1 \times 10^{1} \mathrm{CFU} \mathrm{ml}^{-1}$ $3000 \mathrm{~m}$ from the shore. At this site the highest vibrio concentration was observed in September at 500 $\mathrm{m}$ and in October at the outer station. In Campomarino (Fig. 2d) culturable-vibrio mean concentration was $1.3 \times 10^{1} \mathrm{CFU} \mathrm{ml}^{-1}$ at the station near the coast and $0.8 \times 10^{1} \mathrm{CFU} \mathrm{ml}{ }^{-1} 3000 \mathrm{~m}$ from the shore. The highest vibrio densities were observed in September near the coast and in October at $3000 \mathrm{~m}$. Finally in S. M. al Bagno (Fig. 2e) Vibrio spp. mean abundance was $1.1 \times 10^{1} \mathrm{CFU} \mathrm{ml}^{-1} 500 \mathrm{~m}^{-}$from the coast and $0.7 \times 10^{1} \mathrm{CFU} \mathrm{ml} \mathrm{m}^{-1}$ at $3000 \mathrm{~m}^{2}$ at the outer station with an increase in cell number from August until November.

During the sampling period, 387 Vibrio spp. strains were isolated on TCBS agar plus $2 \% \mathrm{NaCl}$. The temporal succession of the different vibrio species identificated is shown in figure 3. Vibrio mediterranei was the predominant species with a

TABLE 1. - Abiotic parameters measured at the various sampling sites. Temperature $\left({ }^{\circ} \mathrm{C}\right)$, dissolved oxygen $(\%$ Sat.), salinity $(\%)$.

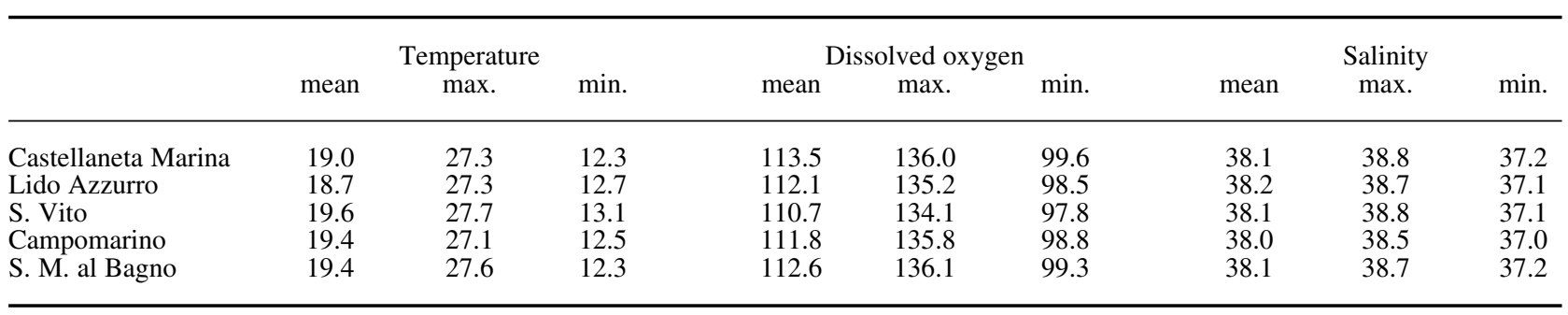


mean isolation percentage of $29 \%$. V. nereis and $V$. harveyi also represented two consistent components of the isolated culturable-vibrio community with mean isolation percentages of 13 and $9 \%$ respectively. V. alginolyticus and V. parahaemolyticus were found to have a mean isolation percentage of $7 \% . \mathrm{V}$. vulnificus, V. mimicus, $V$. aestuarianus and $V$. fluvialis showed a mean isolation percentage of about $5 \%$. The other species were present in low numbers throughout the year: $V$. pelagius I 1\%, V. diazotrophicus $1 \%$, Phenon $53 \%$, V. anguillarum-like 1\%, V. logei $1 \%$, V. campbelli $2 \%$, V. furnissii $1 \%$, V. orientalis $1 \%$, V. proteolyticus $3 \%$, V. anguillarum $1 \%, V$.
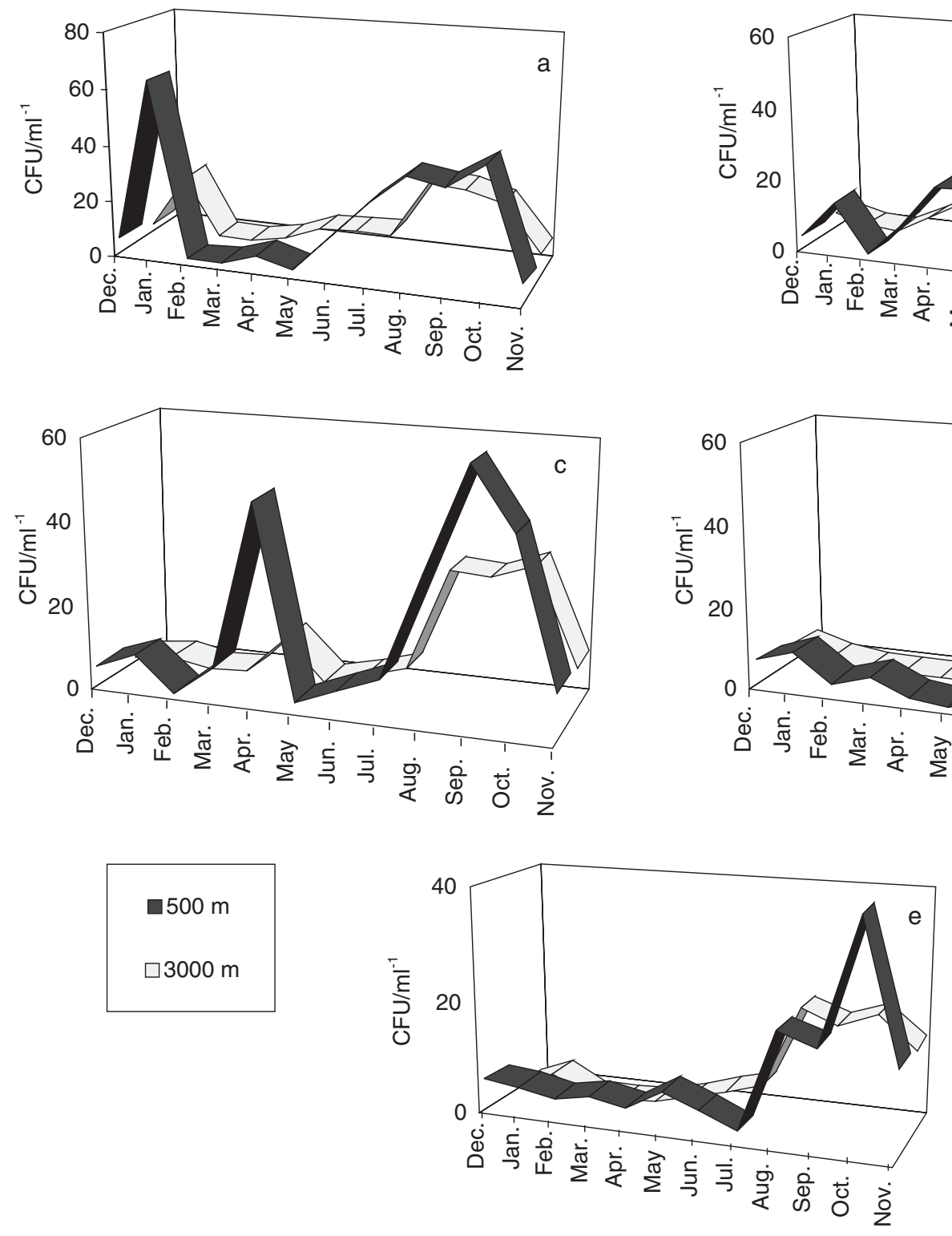

FIG. 2. - Vibrio abundances over an annual cycle in Castellaneta Marina (a), Lido Azzurro (b), S. Vito (c), Campomarino (d) and Santa Maria al Bagno (e). 


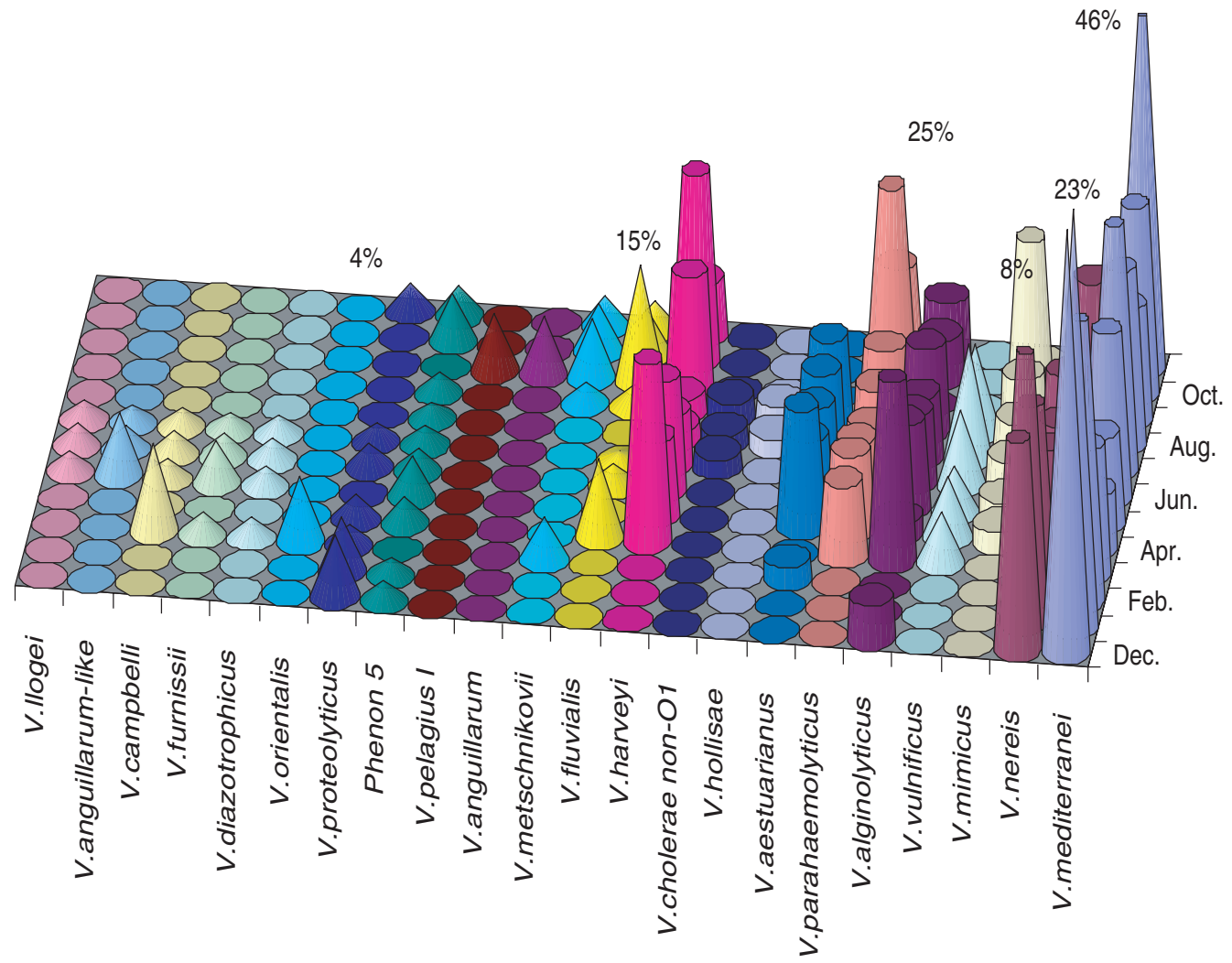

FIG. 3. - Annual trend of vibrios diversity in the Northern Ionian Sea.

\section{DISCUSSION}

The ability to detect potential human pathogens in seawater is vital in assessing the potential public health risk presented by these organisms. In particular, Vibrio infections cannot be prevented unless we know how they are transmitted and the persistence of the microorganisms involved in the marine environment. Before this study, scarce information existed on the distribution of these bacteria in this ecosystem. The identification of environmental Vibrio species presents certain difficulties because of their great diversity. Clinical isolates have been more completely characterized (Alsina and Blanch, 1994).

In the present study vibrio densities were higher at the sites nearest Taranto city (Castellaneta Marina, Lido Azzurro and S. Vito) than at those along the other transects. Such an observation can be explained by the fact that Taranto is an industrial centre whose coastal area receives a significant urban and industrial discharge from the city and from eight nearby towns. Thus, when the temperature is favorable, nutrient loading may stimulate vibrio growth in the transects nearest Taranto at levels higher than those normally sustained by the trophic resources of the Ionian Sea in the unpolluted sites. It is well known that trophic resource availability is one of the most important controls of vibrio abundance. This hypothesis is in accordance with Grimes et al. (1986) who pointed out that many investigators erroneously interpret the wastewater discharge as a source of the pathogens rather than as a source of nutrients, which may stimulate the growth of the autochthonous pathogens.

Usually, in the sites examined, vibrio abundance was low in winter and increased during the summerautumn period. This finding is in agreement with the results of previous environmental studies (Kelly, 1982; Oliver et al., 1983; De Paola, 1994). The seasonality of infections sustained by vibrios corresponds to the ability to readily isolate the vibrios from water, sediment, and mussel samples during warm-water months (Wolf and Oliver, 1992). Attempts during cold water months to isolate several Vibrio species has proved generally unsuccessful (Chowdhury et al., 1990; Oliver, 1995; Colwell, 1996). It has recently been demonstrated that this inability to culture several Vibrio species (e.g., V. vulnificus, V. parahaemolyticus, V. cholerae, V. fischeri, V. harveyi, V. mimicus and V. proteolyticus) from low-temperature environments is not due to cell death but to their viable but nonculturable state; 
this we define as an inability of cells to produce colonies on appropiate solid media even following prolonged incubation (Nilsson et al., 1991; Barcina et al., 1997). Also in our study several Vibrio species such as $V$. vulnificus, $V$. mimicus, $V$. cholerae nonO1, V. logei, V. hollisae, V. diazotrophicus, and V. aestuarianus were sensitive to low water temperatures. In fact, the statistical analysis revealed a significant positive correlation between the temperature and their presence. Thus, further studies will be carried out to evaluate the effects of low temperature during winter on survival of these vibrios species and the presence of a non-culturable state among these microorganisms in the waters of the Northern Ionian Sea.

Concerning vibrios diversity, $V$. mediterranei was the most abundant species isolated throughout the year. This finding is in agreement with other reports which describe $V$. mediterranei among the Vibrio species frequently observed in seawater (Arias et al., 1999; Buck, 1996; Ortigosa et al., 1989, 1994). Seasonal variations in the number of organisms detectable in surface water samples, as observed in Japan (Arai et al., 1980) and in Europe (Schubert, 1981) where positive findings were obtained only in the warm season, are explained by the fact that the bacteria do not multiply at temperatures below $8^{\circ} \mathrm{C}$. In our study $V$. alginolyticus was isolated throughout the year. This temporal distribution could be explained by the minimum temperature value of the studied area $\left(12.3^{\circ} \mathrm{C}\right)$ which seems suitable to $V$. alginolyticus presence considering that the minimum growth temperature for this species is $8^{\circ} \mathrm{C}$ (Blake, 1980). Seawater is the normal habitat for V. alginolyticus, and it has been isolated from seawater and seafood in many parts of the world. The incidence of $V$. alginolyticus could represent a health problem as these bacteria are considered agents of not only miscellaneous infective syndromes (otitis, pharyngitis, wound infections) but also of gastroenterititis.

$V$. parahaemolyticus is part of the normal flora of estuarine and other coastal waters throughout most of the world. It has been isolated from seawater, sea mud or seafoods (De Paola et al., 1990; Macian et al., 2000 b; Mizunoe et al., 2000). Research carried out by various authors on edible molluscs have shown the presence of $V$. parahaemolyticus in Italy, particularly in summer months (Cioglia et al., 1982; Gelosa, 1981). In our study V. parahaemolyticus was absent only in January.

As there have been cholera outbreaks in the Mediterranean sea countries during the last decade, it was particularly interesting to evaluate the presence of these bacteria in the water collected in the Northern Ionian Sea. Studies on the ecology of $V$. cholerae $\mathrm{O} 1$ demonstrated that the incidence of this strain in the water has been related to the salinity and to changes in temperature which appear to be a critical factor in the isolation. Despite the study being conducted over an annual cycle with wide ranges in the water temperature, and a salinity mean value of $38.1 \%$, compatible with occurrence of Vibrio species (Mc Dougald et al., 1998), none of the examined samples were positive to $V$. cholerae $\mathrm{O} 1$ isolation.

We would like to stress the usefulness of our research, not only as regards the species mentioned above, but also with regard to the other halophilic vibrios isolated in the waters of the Apulian coasts of the Northern Ionian Sea. Among them, the presence of Vibrio harveyi was remarkable. Besides their well described mutualistic symbioses in the light organs of certain fishes, these bacteria also occur on the surfaces (saprophytic), in the vital fluids (parasitic), and within the gastrointestinal contents of marine organisms. In these associations they can attain very high numbers. The relationship between these associated bacterial populations and the marine organisms is not well known, although it has beeen suggested that marine organisms may contribute to the survival and distribution of luminous bacteria in the marine environment (Pujalte et al., 1999). Therefore, further studies will be carried out to establish if marine organisms represent a niche for proliferation and distribution of these bacteria in the Northern Ionian Sea on account of the percentage of isolation observed for this species and the constant presence throughout the sampling year. In the investigated area the classical pollution microbial indicators were present at low levels (data not shown); thus, on the basis of the results obtained concerning the distribution of some potentially pathogenic vibrios, we can conclude that the traditional indices of fecal contamination alone are not reliable indicators of the quality of water. Thus a combination of analytical criteria seems to be called for in evaluating seawater quality and the transmission of disease.

\section{REFERENCES}

Alsina, M. and A. R. Blanch. - 1994. A set of keys for biochemical identification of environmental Vibrio species. Jour. Appl. Bacteriol. 76: 79-85. 
Arai, T., N. Ikejima, T. Itoh, S. Sakai, T. Shimada and R. Sakazaki. - 1980. A survey of Plessiomonas shigelloides from aquatic environment, domestic animals, pets and humans. J. Hyg. 84: 203-211.

Arias, C.R., M.C. Màcian, R. Aznar, E. Garay and M.J. Pujalte. 1999. Low incidence of Vibrio vulnificus among Vibrio isolates from sea water and shellfish of the western Mediterranean coast. J Appl Microbiol., 86(1): 125-34.

Barcina, L., P. Lebaron and J. Vives-Rego. - 1997. Survival of allochtonous bacteria in aquatic systems: a biological approach. FEMS Microbiol. Ecol., 23: 1-19.

Blake, P.A. - 1980. Diseases of humans (other than cholera) caused by vibrios. Ann. Rev. Microbiol., 34: 341-367.

Bordas, M.A., M.C. Balebona, J.M.Rodriguez-Marotto, J.J. Borrego and M.A. Moriñigo. - 1998. Chemotaxis of pathogenic Vibrio strain towards mucus surfaces of gilt-head Sea Bream (Sparus aurata L.). Appl. Environ. Microbiol., 64 (4): 15731575 .

Buck, J.D. - 1990. Potentially pathogenic marine Vibrio species in seawater and marine animals in the Sarasota, Florida, area. $J$. Coast. Res., 6: 943-948.

Chowdhury, M.A.R., H. Yamanaka, S. Miyoshi and S. Shinoda. 1990. Ecology and seasonal distribution of Vibrio parahaemolyticua in aquatic environments of a temperate region. FEMS Microbiol. Ecol., 74: 1-10.

Cioglia, A.M., M. San and A.M. Uccheddu. - 1982. Reperto di vibrioni alofili nelle acque litoranee e lagunari di Cagliari e nei prodotti ittici (molluschi e pesci) derivanti da esse o in vendita nei mercati della città. Ig. Mod., 77: 199-211.

Colwell, R.R.. - 1994. Vibrios in the marine and estuarine environment. In: 3th International Marine Biotechnology Conference. Tromsoe, Norway, 7-12 Aug.

Colwell, R.R.. - 1962. The bacterial flora of Puget Sound fish. $J$. Appl. Bacteriol., 25: 147-158.

Colwell, R.R.. - 1996. Global climate and infectious disease: the cholera paradigm. Science, 274: 2025-2031.

De Paola, A. L.H. Hopkins, J.T. Peeler, B. Wentz and R.M. McPhearson. - 1990. Incidance of Vibrio parahaemolyticus in U.S. coastal waters and oysters. Appl. Environ. Microbiol., 8: 22992302.

De Paola, A., G.M. Capers and D. Alexander. - 1994. Densities of Vibrio vulnificus in the intestines of fish from the U.S. Gulf Coast. Appl. Environ. Microbiol., 60: 984-988.

Ducklow, H.W.. - 1983. Production and rate of bacteria in the oceans. Bio. Sc., 33: 494-501.

Gelosa, L. - 1981. Caratterizzazione dei vibrioni alofili isolati da mitili del commercio a Milano. Ig. Mod., 76: 531-539.

Gilmour, A., M.F. McCallum and M.C. Allan. - 1976. A study of the bacterial types occurring on the skin and in the intestines of farmed plaice (Pleuronectes platessa L.). Aquaculture, 7: 161172.

Grimes, D.J., R.W. Atwell, P.R. Brayton, L.M Palmer, D.M. Rollis, D.B. Roszak, F.L. Singleton, M.L. Tampling and R.R. Colwell. - 1986. The fate of enteric pathogenic bacteria in estuarine and marine environments. Microbiol. Sci., 3: 324-329.

Høi, L., J.L. Larsen, I. Dalsgaard and A. Dalsgaard. - 1998. Occurrence of Vibrio vulnificus biotypes in Danish marine environments. Appl. Environ. Microbiol., 64 (1): 7-13.

Holt, J.G., N.R. Kreig, P.H.A. Sneath, J.T. Staley and S.T. Williams (eds.). - 19949. Bergey's Manual of Determinative Bacteriology. Williams and Wilkins, Baltimore, MD.

Huq, A., P.A. West, E.B. Small, M.I. Huq and R.R. Colwell. 1983. Ecological relationships between Vibrio cholerae and plankton crustacean copepods. Appl. Environ. Microbiol., 45: 275-283.

Jørgensen, B.B.. - 1983. Processes at the sediment-water interface. In: B. Bolin and R.B. Cook, (eds.), The major biochemical cycles and their interactions, pp. 477-515. Wiley, New York.

Kaspar, C.W. and M.L. Tamplin. - 1993. Effects of temperature and salinity on the survival of Vibrio vulnificus in seawater and shellfish. Appl. Environ. Microbiol., 59: 2425-2429.

Kelly, M.T. - 1982. Effect of temperature and salinity on Vibrio (Beneckea) vulnificus occurrence in a Gulf Coast environment. Appl. Environ. Microbiol., 44: 820-824.

MacFarlane, R.D., J.J. McLaughlin and G.L.Bullock. - 1986. Quantitative and qualitative studies of gut flora in striped bass from estuarine and coastal marine environments. J. Wildl. Dis., 22: $344-348$.
Macian, M.C., E. Garay, F. Gonzalez-Candelas, M.J. Pujalte and R. Aznar. - 2000a. Ribotyping of vibrio populations associated with cultured oysters (Ostrea edulis). Syst. Appl. Microbiol., 23(3): 409-17.

Macian, M.C., C.R. Arias, R. Aznar, E. Garay and M.J. Pujalte. 2000b. Identification of Vibrio spp. (other than V. vulnificus) recovered on CPC agar from marine natural samples. Int. Microbiol., 3(1): 51-3.

McDougald, D, S.A. Rice, D. Weichart and S. Kjelleberg. - 1998. Nonculturability: adaptation or debilitation? FEMS Microbiol. Ecol., 25: 1-9.

Miles, D.W., T. Ross, J. Olley and T. A. McMeekin. - 1997. Development and evaluation of a predictive model for the effect of temperature and water activity on the growth rate of Vibrio parahaemolyticus. Int. J. Food Microbiol., 38: 133-142.

Mizunoe, Y., S.N. Wai, T. Ishikawa, A. Takade and S.Yoshida 2000. Resuscitation of viable but nonculturable cells of Vibrio parahaemolyticus induced at low temperature under starvation. FEMS Microbiol. Lett., 186: 115-120.

Montanari, M.P., C. Pruzzo, L. Pane and R.R. Colwell. - 1999. Vibrios associated with plankton in a coastal zone of the Adriatic Sea (Italy). FEMS Microb. Ecol., 29: 241-247.

Montilla, R., J. Palomar, M.C. Fusté and M. Viñas. - 1995. Taxonomy and protein fingerprinting of halophilic Vibrio isolates from bivalves of the Ebre delta. Can J Microbiol., 41(1): 64-9.

Motes, M.L., A. DePaola, D.W. Cook, J.E. Veazey, J.C. Hunsucker, W.E. Garthright, R.J. Blodgett and S.J. Chirtel. - 1998. Influence of water temperature and salinity on Vibrio vulnificus in northern Gulf and Atlantic Coast oysters (Crassostrea virginica). Appl. Environ. Microbiol., 64: 1459-1465.

Nealson, K.H., M.G. Haygood, B.M. Tebo, M. Roman, E. Miller and J.E. McCosker. - 1984. Contribution by symbiotically luminous bacteria to the occurence and bioluminescence of luminous fishes. Microb. Ecol., 10: 69-77.

Nilsson, L., J.D. Oliver and S. Kjelleberg. - 1991. Resuscitation of Vibrio vulnificus from the viable but nonculturable state. Jour. Appl. Bacteriol., 173: 5054-5059.

Oliver, J.D. - 1995. The viable but non-culturable state in the human pathogen, Vibrio vulnificus. FEMS Microbiol. Lett. 133: 203-208.

Oliver, J.D., R.A. Warner and D.R. Cleland. - 1983. Distribution of Vibrio vulnificus and other lactose-fermenting vibrios in the marine environment. Appl. Environ. Microbiol., 45: 985-998.

Ortigosa, M., C. Esteve and M.J. Pujalte. - 1989. Vibrio species in seawater and mussels: Abundance and numerical taxonomy. Syst. App. Microbiol., 12: 316-325.

Ortigosa, M., E. Garay and M.J. Pujalte. - 1994. Numerical taxonomy of aerobic, gram-negative bacteria associated with oysters and surrounding seawater of the Mediterranean coast. Syst. Appl. Microbiol., 17: 589-600.

Pujalte, M.J., M. Ortigosa, M.C. Macian and E. Garay. - 1999. Aerobic and facultative anaerobic heterotrophic bacteria associated to Mediterranean oysters and seawater. Int Microbiol., 2(4): 259-66.

Ruby, E.G. and J.G. Morin. - 1979. Luminous enteric bacteria of marine fishes: a study of their distribution, densities, and dispersion. Appl. Environ. Microbiol., 38: 406-411.

Sakata, T., M. Nakaji and D. Kakimoto. - 1978. Microflora in the digestive tract of marine fish. I. General characterization of the isolates from yellowtail. Mem Fac. Fish. Kagoshima Univ., 27. 65-71.

Schubert, R.H.W. - 1981. Zür Ökologie von Plessiomonas shigelloides. Zentralbl. Bakteriol. Parasitenkd. Infektionskr. Hyg. Abt. I Orig. B., 172: 528-533.

Sera, H. and Y. Ishida. - 1972. Bacterial flora in digestive tracts of marine fish. III Classification of isolated bacteria. Bull. Jpn. Soc. Sci. Fish., 38: 853-858.

Statsoft. - 2001. Electronic statistics textbook. Statsoft, Tulsa, OK.

Ugajin, M. - 1979. Studies on the taxonomy of major microflora on the intestinal contents of salmonids. Bull. Jpn. Soc. Sci. Fish., 45: 721-731.

Wolf, P.W. and J.D. Oliver. - 1992. Temperature effects on the viable but non-culturable state of Vibrio vulnificus. FEMS Microb. Ecol., 101: 33-30.

Yoshimizu, M.T. Kimura and M. Sakai. - 1976. Studies on the intestinal microflora of salmonids. I. The intestinal microflora of fish reared in fresh water and sea water. Bull. Jpn. Soc. Sci. Fish., 42: 91-99. 
